\title{
Yazarlar ve Edebî Dönemler Bağlamında Cumhuriyet Öncesi Türk Hikâyelerindeki Aile ile İlgili Konulara Genel Bir Bakışs
}

\section{YAVUZ SELIMM UĞURLU*}

Öz

Edebî eserlerin temel konusu olan insan, bir toplum içinde yaşamaktadır. Her insan doğar doğmaz bir aile sahibi olur. İşte bu noktada edebiyat ile sosyolojinin yolları kesişir. Edebiyat, insanı toplumun en küçük birimi olan aile içerisinde ele alır. Bu da gerek edebiyat-aile gerekse sosyoloji-aile arasındaki ilişkiye işaret eder. Aileyi işleyen tahkiyeli türler içerisinde hikâye önemli bir yer tutmaktadır. Tanzimat Dönemi'yle Cumhuriyet'in ilan edilişi arasındaki süre Türk halkı açısından değişimin, Türk edebiyatı açısından da yeni türlerin girişiyle birlikte sanat anlayışındaki farklılaşmanın meydana geldiği bir zaman dilimidir. 1870-1923 arasındaki zaman diliminde Ahmet Mithat Efendi, Samipaşazade Sezai, Halit Ziya Uşaklıgil, Ömer Seyfettin, Ahmet Rasim başta olmak üzere birçok yazar hikâyelerinde aile konusunu işler. Bu eserlerde okur, aile ile ilgili olarak ailenin kuruluşu ve gelişmesi, aile içi ilişkiler, aile ve günlük hayat, aileyi dağıtan veya derinden etkileyen olaylar başta olmak üzere birçok konuyla karşılaşır. Bu çalışmada bahsi geçen yazarların Cumhuriyet öncesi döneme ait hikâyelerinde aile ile ilgili hangi konulara yer verdikleri edebî dönemler bağlamında ele alınmıştır.

Anahtar sözcükler: Hikâye, Aile, Edebiyat, Cumhuriyet Öncesi Dönem, Edebî Dönemler

\section{AN OVERWIEW OF ISSUES RELATED TO FAMILY IN PRE-REPUBLICAN TURKISH STORIES IN THE CONTEXT OF AUTHORS AND LITERARY PERIODS}

\section{Abstract}

Human, the main subject of literary works, lives in a society. Every person has a family as soon as $\mathrm{s} /$ he is born. At this point the paths of literature and sociology cross. The literature deals with human as a member of the family, the smallest unit of society. This indicates the relationship between both literature-family and sociology-family. The story has a significant place among the narrative genres that handle family. The period between the Tanzimat Era and the proclamation of the Republic is a time period that refers to a change for Turkish society and also that refers to the differentiation in the understanding of art with the introduction of new genres in terms of Turkish literature. In the time period between 1870-1923, many authors, including Ahmet Mithat Efendi, Samipaşazade Sezai, Halit Ziya Uşaklıgil, Ömer Seyfettin, Ahmet Rasim, deal with the family issue in their stories. In these works, the reader confronts with many topics, such as the establishment

\footnotetext{
* Bu makale, Yavuz Selim Uğurlu'nun hazırlamakta olduğu Cumhuriyet Öncesi Türk Hikâyelerinde Aile Kurumu adlı doktora tezinden üretilmiştir.

** Giresun Ün. Sos. Bil. Ens. TDE doktora program1, yavuzs.ugurlu52@gmail.com, orcid.org/0000-0002-5289-227X 
and development of family, family relations, family and daily life, events that distribute or deeply affect the family. In this study, the issues related to family in mentioned authors' stories belonging to the pre-Republican period were discussed in the context of literary periods.

Keywords: Story, Family, Literature, Pre-Republic Period, Literary Periods

\section{GİRIŞ}

$\Gamma$ ürk edebiyatını dönemlere ayırma hususunda birçok farlı tasnif şekli mevcuttur. Bu tasniflerden en geçerli olanı Mehmet Fuat Köprülü'nün Türk edebiyatının devirlerini İslamiyet Öncesi, İslâmî Dönem ve Batı Etkisi Altındaki Türk Edebiyatı şeklinde isimlendirdiği tasnifidir. Edebî dönemler bağlamında Cumhuriyet Öncesi Türk Edebiyatı Dönemi'ne ait hikâyelerde ailenin nasıl ele alındığını ortaya çıkarmaya çalıştığımız bu çalışmada Batı Etkisi Altındaki Türk Edebiyatı Devri'ni Tanzimat, Servetifünun, Fecriati ve Millî Edebiyat Dönemi şeklinde ele alacağız.

Türk edebiyatında modern hikâye, Osmanlının Batı'ya yönünü çevirmesinden sonra yani Tanzimat ve sonraki süreçte görülmeye başlar. Buna göre Cumhuriyet Öncesi Dönem Türk hikâyeciliği; Tanzimat Dönemi hikâyeciliği, Servetifünun Dönemi hikâyeciliği, Fecriati ve Millî Edebiyat Dönemi hikâyeciliği şeklinde dört ana dönem hâlinde ele alınabilmektedir. Ayrıca Ara Nesil hikâyecileri, Servetifünun ve Fecriati Dönemlerinde hikâye türünde eser verip bu dönemler dâhilinde sayılmayan isimler de Cumhuriyet Öncesi Dönem Türk hikâyeciliği kapsamında değerlendirmeye tâbî tutulmaktadır.

Tanzimat Dönem'inde Türk hikâyeciliğinde başlayan yenileşme kısa bir sürede tamamlanmaz. Bu değişim ilk zamanlarda sonraki dönemlere göre daha yavaş gerçekleşir Modern bir Türk hikâyeciliğinden bahsedebilmek için Samipaşazade Sezai ve Halid Ziya'yı beklemek gerekir. Bu yazarlarda bile geleneğinin etkisinin tamamen kaybolduğu söylenemez (Demir, 2006, s. 100).

Edebiyat içinde bulunduğu toplumu yansıtırken o toplumun en temel birimi olan aileye de yer verir. Türk toplumu için önemli bir kurum olan aile, Türk edebiyatının her devrinde gerek ana tema gerekse ana temayı destekleyen işlevde birçok edebî tür kullanılarak işlenmiştir. Aileye değinen bu türlerden biri de hikâyedir

1800'lü yılların son çeyreğinden itibaren ortaya çıkı gelişmeye başlayan modern Türk hikâyeciliği, toplumu dolayısıyla onun en küçük birimi olan aileyi ele alan edebî türlerden biridir. Türk hikâye yazarları insanı, toplumu, kültürü eserlerinde konu olarak kullanır ve bunlardaki her türlü değişimi eserlerine yansıtırlar. Aile, geniş bir konu dağılımına sahip olan Türk hikâyeciliği içerisinde yazarların sıklıkla başvurduğu bir konudur.

\section{TANZIMAT DÖNEMI SANATÇILARININ HİKÂYELERİNDE AİLE}

1839'da Tanzimat Fermanı'nın ilanı sonrasındaki süreçte Hazırlık Dönemi, 1. Dönem ve 2. Dönem şeklindeki evrelerle gelişim gösteren Batı Etkisi Altındaki Türk Edebiyatı Devri'nin bu ilk dönemi birçok bakımdan Türk edebiyatındaki değişimin kendisini en fazla hissettirdiği dönem olur. Bu değişim sadece edebî yaşama değil toplumsal yaşama da hâkimdir. Toplumsal yaşamın bir 
parçası olan aile de bu değişimden etkilenir. Tanzimat Dönemi hikâye yazarları eserlerinde aile ve ondaki değişimi eserlerine yansitırlar.

$\mathrm{Bu}$ dönemde edebiyatımıza giren birçok Batılı edebî türden biri de modern hikâye türüdür. Tanzimat Dönemi'nde modern hikâye tarifine uygun ilk telif hikâye örnekleri Samipaşazade Sezai'nin Küçük Şeyler'inde görülür. Bu hikâyeler bugün de okunabilirliğini devam ettiren Maupassant tarzı denilen olay hikâyeleridir. Türk edebiyatında hikâye sahasında Anadolu köyü ve çiftçisinin hayatına eğilen ilk eser olan N. Nazım'ın Karabibik, adlı uzun hikâyesi de aynı tarihe denk gelir (Kabakl1, 1971, s. 551).

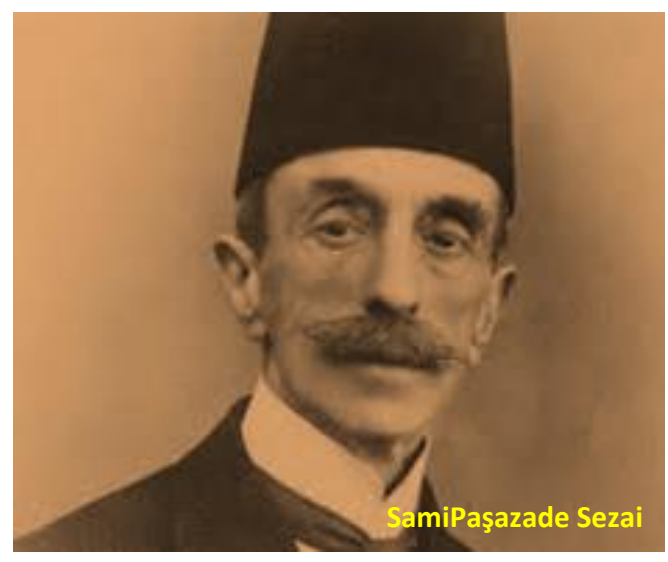

Tanzimat Dönemi hikâyeciliğinin öncü ismi olan Ahmet Mithat Efendi'nin hikâyelerinde aile ile ilgili konulara sıklıkla rastlanır. Onun Letaif-i Rivâyât adlı hikâye külliyâtındaki birçok hikâyede aileye yardımcı elemanlar, ailede eğitim, yabancı aileler, aldatma, aile içi ilişkiler gibi konuları başta olmak üzere birçok farklı konu okuyucunun karşısına çıkar.

Yazarın Durub-ı Emsal-i Osmaniye: Şinasi Hikemiyâtının Ahkâmı -Tasvir-adlı eseri Şinasi'nin atasözlerini derlediği sözlüğü olan Durub-ı Emsal-i Osmaniye'den seçtiği her bir atasözüne bir kısa hikâye yazmasıyla oluşmuş kitaptır. Hikâyelerde boşanma, aldatma, aile içi ilişkiler, aile ve miras başta olmak üzere aile ile ilgili birçok meseleye değinilir.

Hikâye türündeki eserlerinde ölüm ve aile konusunu sıklıkla işleyen Tanzimat 2. Dönem sanatçılarından Samipaşazade Sezai Batılı anlamda ilk hikâye örneklerini Küçük Şeyler adlı hikâye kitabıyla verir. Onun bu eserinde aileyle ilgili olarak fakir aileler, karı-koca ilişkisi, yabancı aileler, aileye yardımcı elemanlar aile ve sağlık, eş seçimi ve eşlerde aranan özellikler, aile ve ölüm konuları işlenir. Yazarın Rumuz'ul Edep ve İclâl adlı eserlerindeki aile ile ilgili olan hikâyelerde aile ve ölüm, aile ve sağlık meselelerine değinilir.

Bu dönemin diğer ismi Recaizade Mahmut Ekrem'in Şemsa, Muhsin Bey yahud Şâirliğin Hazin Sonu adlı eserlerinde aile-hastalık ve aile-ölüm konuları işlenir. Emin Nihat'ın Müsameretname adlı eserinde; yabancı aileler, eş seçimi ve eşlerde aranan özellikler, aileye yardımcı elemanlar konuları aileyle ilgili en fazla işlenen konulardır. Manastırlı Mehmet Rıfat'ın Gönüllü-Henüz On Altı Yaşında adlı eserindeyse tanışma, anlaşma ve evlenmeye karar verme yanında aile ve gündelik hayat konuları işlenir.

Ara nesil, Türk edebiyatında Tanzimat sonrası ikinci kuşak olan, Recaizade Mahmut Ekrem, Muallim Naci ve Abdülhak Hâmid'le Servetifünun edebiyatı arasında eser vermiş yazarların içinde bulunduğu devreye verilen addır. Bu devre 1876-1896 zaman dilimini kapsar. Ara nesil içerisinde hikâye türünde eser veren önemli sanatçılar: Nabizade Nâzım, Mehmet Celâl, Mustafa Reşid, Fatma Makbule Leman'dır.

Nabizade Nâzım'ın Karabibik adlı uzun hikâyesinde eş seçimi ve eşlerde aranan özellikler; aile ve sağlık; aldatma; süt anne, süt baba, süt kardeş-çocuk ilişkisi; fakir aileler; çiftçi aileleri; aile ve gündelik hayat konuları işlenir. Yazarın Sevdâ adlı eserinde evlenme nedeni, Hâlâ Güzel'de 
mutsuz aileler, boşanma ve yeniden evlenme; Bir Hatıra ve Zavallı Kız'da aile ve ölüm konusu işlenir. Fatma Makbule Leman'ın Makes-i Hayâl adlı eserinde yer alan hikâyelerde aile ile ilgili meselelerden özellikle aile ve eğitim konusuna yer verilir. Ara neslin bir diğer önemli yazarı kabul edilen ve birçok eserinin hikâye mi roman mı sayılacağı konusunda bir netlik olmayan Mehmet Celâl'in Mustafa Reşit'in eserlerinde aile ve ölüm, aile ve gündelik hayatın yanı sıra aile içi ilişkiler konuları çoğunlukla işlenir. Mustafa Reşid'in Bir Çiçek Demeti ve Tesâvir-i Hayat adlı eserlerindeyse hikâye kahramanlarının ve yazarlarının aile ve aileyle ilgili meselelere bakışı, eş seçimi ve eşlerde aranan özellikler konuları ele alınır.

\section{SERVETİFÜNUN DÖNEMİ SANATÇILARININ HİKÂYELERİNDE AİLE}

Servetifünuncular ortak bir dergi etrafinda toplanan akranlar kümesi hüviyetindedir. Onlar, önceki dönemlere nazaran şiir konularını genişletirler. Hikâye ve romanda psikolojiye daha çok önem verirler. Bu dönem, aslında 19. yy. ortalarından sonra başlayan Batılılaşmanın biraz daha uzmanlaşmış şeklidir. Bu kısa zaman dilimi sadece beş-altı yıllık bir dergi-kitap yayınıla edebiyattaki boşluğu gidermeye çalışır (Mutluay, 1976, s. 48).

Bu dönem hikâyeciliğinin usta ismi Halit Ziya Uşakligil'in birçok hikâyesinde aile ile ilgili birçok konuya yer verilmiştir. Yazarın Bir Yazın Tarihi adlı hikâye kitabında aile ve ölüm, yabancı aileler, aile ve gündelik hayat, aldatma, hikâye kahramanlarının ve yazarlarının aile ve aileyle ilgili meselelere bakışı, aileye yardımcı elemanlar, aile ve sağlık, aile içi ilişkiler konuları işlenir. Halit Ziya Uşaklıgil'in Sepette Bulunmuş adlı hikâye kitabında ise sanatçı aileler konusu ele alınır. Yazarın Bir Hikâye-i Sevdâ adlı hikâye kitabında eşlerden birinin aileden uzaklaşması, aile içinde engelli bireyler, kız isteme, görücüye çıkma, söz kesimi, nişanlanma ve nişanlılık süreci, aile ve ekonomik çöküş, azınlık aileleri, aileye damat (iç güvey) gelişi fakir aileler konuları ele alınır. Solgun Demet adlı hikâye kitabında mutsuz aileler ve mutsuzluk sebepleri, zanaatkâr aileler, başlık parası, çeyiz ve mehir konuları ele alınır.

Yazarın Bu Muydu? adını verdiği içinde tek hikâye bulunan eserinde; tanışma, anlaşma ve evlenmeye karar verme konusu işlenirken Bir İzdivacın Tarih-i Muaşakası adlı içinde tek hikâye barındıran diğer bir kitabında tanışma, anlaşma ve evlenmeye karar verme yanında aile içi ilişkiler konusu işlenir. Yazarın Bir Muhtıranın Son Yaprakları adlı başka bir tek hikâyelik eserinde ise içi ilişkiler konusu ele alınır. Yazarın tek hikâyelik kitaplarından bir diğeri olan Heyhat'ta ise hikâye kahramanlarının ve yazarlarının aile ve aileyle ilgili meselelere bakışı vardır.

Halit Ziya Uşakligil Bir Şi'ir-i Hayâl adlı hikâye kitabında aileyle ilgili şu konuları ele alır: Aileye damat (iç güveyi) gelişi, zengin aileler, azınlık aileleri, fakir aileler, hikâye kahramanlarının ve yazarlarının aile ve aileyle ilgili meselelere bakışı, aile ve hastalık, aile içi ilişkiler ve balıkçı aileleri. Yazarın Nakil adlı hikâye kitabındaysa doğum ve çocuk sahibi olma, asker ve sanatçı aileler konuları işlenir.

Servetifünun'un bir diğer hikâyecisi Mehmet Rauf'un Son Emel adlı eserinde hikâye kahramanlarının ve yazarlarının aile ve aileyle ilgili meselelere bakışı ve aile ve gündelik hayat konuları işlenir. Üç Hikâye'de evlenme nedeni, aile içi ilişkiler, aile ve gündelik hayat, fakir aileler, eş seçimi ve eşlerde aranan özellikler; tanışma, anlaşma ve evlenmeye karar verme konuları işlenir. 
Âşıkâne'de mutsuz aileler ve mutsuzluk sebepleri konusu işlenir. Hanımlar Arasında'da hikâye kahramanlarının ve yazarlarının aile ve aileyle ilgili meselelere bakışı, aile ve gündelik hayat, aldatma, aile içi ilişkiler; tanışma, anlaşma ve evlenmeye karar verme; kız isteme, görücüye çıkma, söz kesimi, nişanlanma ve nişanlılık süreci; eş seçimi ve eşlerde aranan özellikler, ilk evliliğin herhangi bir sebeple bitmesi sonrası evlenme, çok yaşlı bir erkekle çok genç bir kadının evlenmesi konuları işlenir. İhtizar' da hikâye kahramanlarının ve yazarlarının aile ve aileyle ilgili meselelere bakışı, aldatma, aile içi ilişkiler; bir erkeğin kendinden yaşça büyük bir kadınla evlenmesi, mutsuz aileler ve mutsuzluk sebepleri, aile ve hastalık, aile ve ölüm konuları işlenir. İlk Temas İlk Zevk'te evdeki hizmetlilerle evlenme, aile içi ilişkiler, mutsuz aileler ve mutsuzluk sebepleri, asker aileleri, yabancı aileler, aile ve eğitim, ilk evliliğin herhangi bir sebeple bitmesi sonrası evlenme, eşlerden birinin aileden uzaklaşması; kına gecesi, nikâh ve düğün; bir erkeğin kendinden yaşça büyük bir kadınla evlenmesi, boşanma konuları işlenir. Pervaneler Gibi'de aldatma, aile içi ilişkiler, aile ve gündelik hayat, memur aileleri; kız isteme, görücüye çıkma, söz kesimi, nişanlanma ve nişanlılık süreci; aile ve eğitim konuları işlenir. Kadın İsterse'de aldatma, ilk evliliğin herhangi bir sebeple bitmesi sonrası evlenme, çok yaşlı bir erkekle çok genç bir kadının evlenmesi ve aile ve gündelik hayat konuları işlenir.

Hüseyin Câhit Yalçın'ın Hayat-ı Muhayyel'de mutlu aileler ve mutluluk sebepleri; kız isteme, görücüye çıkma, söz kesimi, nişanlanma ve nişanlılık süreci; kına gecesi nikâh ve düğün, aile ve ölüm, eşlerden birinin aileden uzaklaşması, aile ve hastalık, aile içi ilişkiler konuları işlenir. Hayat1 Hakikiye Sahneleri'nde aile ve ölüm, fakir aileler, boşanma, aile eğitim, mutsuz aileler ve mutsuzluk sebepleri, aile ve gündelik hayat konuları yer alır. Yazarın Niçin Aldatırlarmış adlı eserindeyse aldatma konusu işlenir.

Safvetî Ziya'nın Bir Safha-i Kalp'te aldatma, aileye yardımcı elemanlar, aile ve gündelik hayat, hikâye kahramanlarının ve yazarlarının aile ve aileyle ilgili meselelere bakışı konuları yer alır. Hanım Mektupları'nda hikâye kahramanlarının ve yazarlarının aile ve aileyle ilgili meselelere bakışı, eş seçimi ve eşlerde aranan özellikler konuları işlenir. Kadın Ruhu'nda ise zengin aileler konusu vardir.

Ahmet İhsan Tokgöz'ün Küçük Fıkralar adlı eserinde fakir aileler, aile ve eğitim, aile ve hastalık konuları işlenir. Yazarın Bahse Ne Dersiniz? adlı eserindeyse evlenme nedeni konusu işlenir. Sanatçının Postacı adlı eserindeyse aldatma konusu ele alınır.

Servetifünun, Fecriati ve Millî Edebiyat anlayışlarının edebî ortama hâkim olduğu dönemlerde eser vermelerine rağmen bu gruplara katılmayan bazı yazarlar da mevcuttur. Hüseyin Rahmi, Ahmet Rasim başta olmak üzere Mehmet Vecihî ve Abdullah Zühdî gibi isimler bu grupta sayılabilir.

Hüseyin Rahmi Gürpınar'ın Kadınlar Vaizi adlı hikâye kitabında ilk evliliğin herhangi bir sebeple bitmesi sonrası evlenme, bir erkeğin kendinden yaşça büyük bir kadınla evlenmesi, aldatma, aileye yardımcı elemanlar, aile ve günlük hayat, aileye yardımcı elemanlar, aile içi ilişkiler ve boşanma konusu işlenir.

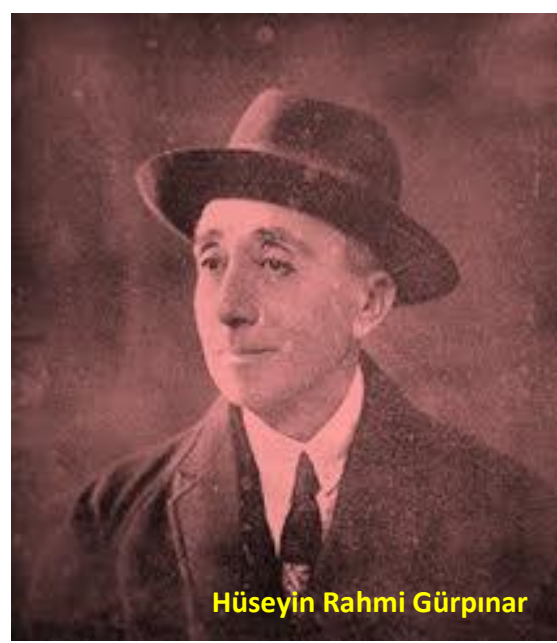


Ahmet Rasim'in İki Güzel Günahkâr adlı hikâye kitabında boşanma ve ölüm konuları işlenir. Yazarın İki Güzel-Hamamcı-Ülfet adlı hikâye kitabında evlenme nedeni; başlık parası, çeyiz ve mehir; aile bireylerinin dinî yaşamının aile içi yaşama yansıması konuları ele alınır. Yazarın Bir Sefilenin Evrâk-ı Metrûkesi adlı eserindeyse aldatma konusu işlenir. Sanatçının bir diğer eseri olan Mehâlik-i Hayat'ta ise aileye yardımcı elemanlar, aile ve günlük hayat konuları işlenir. Meyl-i Dil adlı eserinde işlenen konular ise aile içi ilişkiler; yanı sıra aile ve sağlıktır. Sanatçının İhanet-i Aşk ismini verdiği eserinde eş seçimi ve eşlerde aranan özellikler yer alır. Tecârib-i Hayat'ta aileyle ilgili konu olarak okuyucunun karşısına aldatma çıkmaktadır. Afife'de ise kız isteme/görücüye çıkma, söz kesimi, nişanlanma ve nişanlılık süreci konuları işlenir. Yazarın Numûne-i Hayâl adlı hikâye kitabında eş seçimi ve eşlerde aranan özellikler yanı sıra aile ve sağlık konusu işlenir. Sanatçının Sevdâ-yı Sermedî adlı kitabında aileyle ilgili olarak işlenen konular aile ve ölümün yanı sıra aile ve sağlıktır. Hevâa-yı Aşk'ta ölüm ve kız kardeşlerle erkek kardeşler arasındaki ilişki konuları yer alır. Endişe-i Hayat'ta aileyle ilgili olarak aldatma, eşlerden birinin hapse girmesi veya sürgüne gönderilmesi konuları yer alır. Yazarın İlk Sevgi adlı eserinde aldatma ve aile içi ilişkiler konuları işlenir. Nâkâm'da ise aileyle ilgili işlenen konular şunlardır: aile ve ölüm, boşanma, aile içi ilişkiler, aile ve sağlık, aile ve miras.

Bu dönemin diğer bir ismi Mehmet Vecihî'nin Nerîme ve Hasbihâl'de aile ve hastalık konusu işlenir. Netice yahud Bir Yetimin Sergüzeşti'ndeyse evlat edinme ve aldatma konuları işlenir. Vuslat'ta ise aile ve gündelik hayat konusu işlenir. Halime' de aile ve ölüm, aldatma, eşlerden birinin aileden uzaklaşması ve fakir aileler konuları işlenir. Hikâye-i Müntahabe Mecmuası'nda ailehastalık ve ölüm, evlat edinme konuları işlenir.

Abdullah Zühdî'nin Rehgüzâr-ı Matbuatta adlı eserindeki bazı hikâyelerde aile ile ilgili olarak başka milletten biriyle evlenme, aldatma, aile içi ilişkiler, aile ve miras, fakir aileler, aile ve ölüm, aile ve gündelik hayat ve boşanma konuları işlenir.

\section{FECRİATI SANATÇILARININ HIKKÂYELERINDE AİLE}

1901 yılında Servetifünun Topluluğu'nun dağılmasından sonra edebiyat dünyasındaki boşluğu doldurmak için bir araya gelen sanatçıların bir beyannameyle kurdukları ve çok kısa bir süre (1909-1912) edebî faaliyetlerini sürdüren ve sonrasında dağılan Fecriati topluluğunda sanatçılar; şiir, roman gibi türler yanında hikâye türünde eseler de kaleme alırlar.

Fecriati topluluğu kısa hikâye türünde kendilerinden bir önceki dönem olan Servetifünun hikâye yazarlarından daha başarılı eserler kaleme almışlardır. Fecriati yazarlarının bu türe karşı ilgisini arttıran en önemli faktörse Alphonse Daudet ve Guy de Maupassant gibi kısa hikâyede şöhreti yakalamış yazarları yakından tanımalarıdır. Topluluk içerisinde Cemil Süleyman, Şahabeddin Süleyman, Refik Halid, Yakup Kadri, Ali Süha ve topluluk etrafında Halide Salih ve Ömer Seyfettin gibi isimler hikâye türünde yetkin örnekler kaleme alır (Şen, 2009, s. 1369)

Cemil Süleyman Alyanakoğlu'nun Timsal-i Aşk adlı eserinde aileyle ilgili olarak kız isteme/görücüye çıkma, söz kesimi, nişanlanma ve nişanlılık süreci; mutsuz aileler ve mutsuzluk sebepleri, aile ve gündelik hayat, aldatma ve aile içi ilişkiler konuları işlenir. Yazarın Ukde adlı hikâye kitabındaysa bir erkeğin kendinden yaşça büyük bir kadınla evlenmesi boşanma, aile içi 
ilişkiler, fakir aileler, azınlık aileleri, hikâye kahramanlarının ve yazarlarının aile ve aileyle ilgili meselelere bakışı ele alınır. İzzet Melih Devrim'in Hüzün ve Tebessüm adlı hikâye kitabında aldatma, aile içi ilişkiler ve aileye yardımcı elemanlar konuları işlenir.

\section{MİLLÎ EDEBIYYAT DÖNEMİ SANATÇILARININ HİKÂYELERİNDE AİLE}

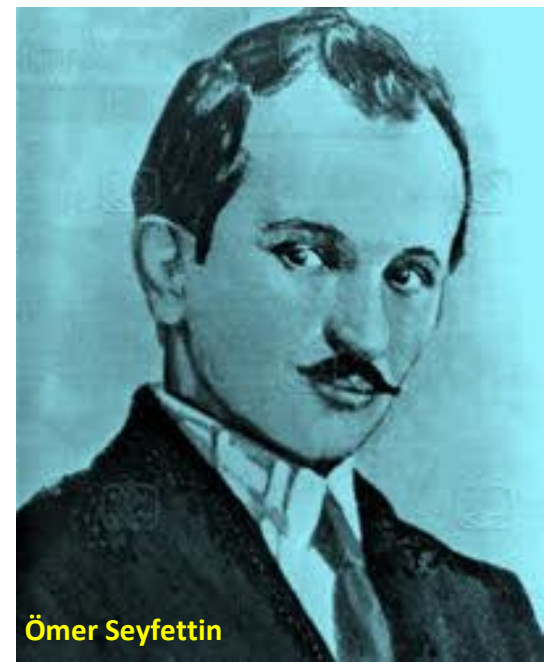

1911 yılında Selanik'te yayımlanmaya başlayan Ömer Seyfettin, Ziya Gökalp ve Ali Canip Yöntem'in çıarttığı Genç Kalemler Dergisi etrafında filizlenen Millî Edebiyat 1923'te Cumhuriyet Dönemi Türk Edebiyatının başlangıcı ve sonrasındaki süreçte de Türk edebiyatında etkisini devam ettirir.

Millî edebiyat Dönemi'nde Tanzimat yıllarında da var olan Türkçülük, ortak bir kabul hâline gelir. Artan millî duyarlılık zaten halkı bilinçlendirme gayretinde olan yazarları milleti ilgilendiren konulara yöneltir. Bu durum hikâye türü için de geçerlidir. Hikâyelerin dilinin sadeleşmesi, dil ve anlatımın günlük hayatta kullanıldığı şekle yaklaşması hikâyeye yeni bir ivme kazandırır (Demir, 2006, s. 109).

$\mathrm{Bu}$ dönem hikâyecilerinden Ömer Seyfettin, Ebubekir Hazim Tepeyran, Ahmet Hikmet Müftüoğlu, Halide Edip Adıvar, Yakup Kadri Karaosmanoğlu, Refik Halit Karay, Fahri Celâl Göktulga, Reşat Nuri Güntekin, Aka Gündüz, Ercüment Ekrem Talu, Münir Süleyman, Selahattin Enis, Osman Cemâl Kaygılı, Peyami Safa, Selami İzzet Sedes, Raif Necdet Kestelli ve M. Şevket Esendal eserlerinde aile ve aile ile ilgili konulara az ya da çok yer verirler.

Bu dönem hikâyeciliğinin öncü ismi olan Ömer Ömer Seyfettin'in hikâyelerinde aile ile ilgili şu konular işlenir: aldatma, aile ve hastalık, aile ve gündelik hayat, fakir aileler, bir erkeğin evliyken tekrar evlenmesi, başka milletten biriyle evlenme, aile ve ölüm, aile bireylerinin dinî yaşamının aile içi yaşama yansıması, yabancı aileler, evlenme nedeni, mutsuz aileler ve mutsuzluk sebepleri, aile ve eğitim, memur aileleri, aileye damat (iç güveyi) gelişi, aile ve ekonomik çöküş, eş seçimi ve eşlerde aranan özellikler; kız isteme, görücüye çıkma, söz kesimi, nişanlanma ve nişanlılık süreci; ilk evliliğin herhangi bir sebeple bitmesi sonrası evlenme, boşanma, bir erkeğin kendinden yaşça büyük bir kadınla evlenmesi, aile içi ilişkiler, aileye yardımcı elemanlar, aile ve miras, aile ve eğitim, aileye yardımcı elemanlar, hikâye kahramanlarının ve yazarlarının aile ve aileyle ilgili meselelere bakışı, boşanma, çok yaşlı bir erkekle çok genç bir kadının evlenmesi ve evlat edinme.

Ebubekir Hazım Tepeyran'ın Eski Şeyler adlı hikâye kitabında yer alan hikâyelerde aile ve hastalık, ilk evliliğin herhangi bir sebeple bitmesi sonrası evlenme, aile içinde fiziksel ve duygusal şiddet, aile içi ilişkiler, mutsuz aileler ve mutsuzluk sebepleri, aileye yardımcı elemanlar, aile ve hastalık; kız isteme, görücüye çıkma, söz kesimi, nişanlanma ve nişanlılık süreci; fakir aileler, aile ve ölüm konuları işlenir.

Ahmet Hikmet Müftüoğlu'nun Çağlayanlar adlı kitabında aileyle ilgili olarak eş seçimi ve eşlerde aranan özellikler, hikâye kahramanlarının ve yazarlarının aile ve aileyle ilgili meselelere 
bakışı, kız isteme, görücüye çıkma, söz kesimi, nişanlanma ve nişanlılık süreci aile içi ilişkiler, aile bireylerinin dinî yaşamının aile içi yaşama yansıması, ölen eşin kardeşiyle evlenme, boşanma, doğum ve çocuk sahibi olma, aldatma konuları ele alınır.

Yazarın Leyla Yahud Bir Mecnun'un İntikamı adlı eserinde aile-savaş, yangın, doğal afet ve kazalar konusu işlenirken Haristan ve Gülistan'da eş seçimi ve eşlerde aranan özellikler; kız isteme, görücüye çıkma, söz kesimi, nişanlanma ve nişanlılık süreci; ölen eşin kardeşiyle evlenme, doğum ve çocuk sahibi olma aile içi ilişkiler, aile bireylerinin dinî yaşamının aile içi yaşama yansıması, hikâye kahramanlarının ve yazarlarının aile ve aileyle ilgili meselelere bakışı, boşanma ve aldatma konuları ele alınır.

Halide Edip Adivar'ın Harap Mabetler adlı kitabında aldatma, aile ve ölüm, aile içi ilişkiler, çok yaşlı bir erkekle çok genç bir kadının evlenmesi, mutsuz aileler ve mutsuzluk sebepleri; Dă̆a Çıkan Kurt'ta ise fakir aileler ve aldatma konuları ele alınır.

Yâkup Kadri Karaosmanoğlu'nun Bir Serencam adlı eserinde eşlerden birinin aileden uzaklaşması aileyle ilgili yegâne konudur.

Refik Halit Karay'ın Memleket Hikâyeleri adlı eserinde aileyle ilgili şu konular işlenir: aldatma, fakir aileler, aile içi ilişkiler, kuma getirme, evlenme nedeni, hikâye kahramanlarının ve yazarlarının aile ve aileyle ilgili meselelere bakışı, aile-alkol, kumar bağımlılığı ve eğlence hayatı; eş seçimi ve eşlerde aranan özellikler, kına gecesi, nikâh ve düğün, eşlerden birinin aileden uzaklaşması.

Fahri Celâl Göktulga'nın Talakıı Selase adlı kitabında kına gecesi, nikâh ve düğün; aldatma, eş seçimi ve eşlerde aranan özellikler yanında aileye yardımcı elemanlar konuları işlenir.

Reşat Nuri Güntekin'in Eski Ahbap adlı eserinde aileyle ilgili olarak aile ve ölüm konusunun yanın sıra ilk evliliğin herhangi bir sebeple bitmesi sonrası evlenme meselesi yer alırken RecmGençlik ve Güzellik'te aile içi ilişkiler konusu işlenir. Yazarın Sönmüş Yıldızlar adlı eserindeyse aldatma, eş seçimi ve eşlerde aranan özellikler, aile ve ölüm, aile ve eğitim, çok yaşlı bir erkekle çok genç bir kadının evlenmesi, boşanma, aile ve hastalık; savaş, yangın, doğal âfet ve kazalar, aile ve ölüm ve fakir aileler konuları ele alınır.

Aka Gündüz'ün Türk Kalbi adlı eserinde aile-savaş, yangın, doğal âfet ve kazalar konusunun yanı sıra eşlerden birinin hapse girmesi veya sürgüne gönderilmesi konusu işlenir. Yazarın Türk'ün Kitabı adlı eserinde aile-savaş, yangın, doğal afet ve kazalar konusu işlenirken Zifaf Hatırâsı'nda tanışma, anlaşma ve evlenmeye karar verme işlenir. Odalı̆̆ın Defteri'nde ise aileyle ilgili olarak işlenen konu aileye yardımcı elemanlardır.

Ercüment Ekrem Talu'nun Teravihten Sahura adlı kitabında aileyle ilgili konular şunlardır: eş seçimi ve eşlerde aranan özellikler, aile ve ölüm, aldatma, aile içi ilişkiler. Münir Süleyman'ın Düğ̈̈n Gecesi-Sağır Güveyin Muaşakası adlı eserinde evlenme nedeni konusu aileyle ilgili bir mesele olarak okuyucunun karşısına çıkar. Selahattin Enis'in Sara adlı eserinde aile ve sağlık konusunun yanında aldatma konusu işlenir. Osman Cemâl Kaygılı'nın Çuvalcı Şeyhi'nin Halefi adlı eserinde aile ve ölüm konusu ele alınırken yazarın Altın Babası adlı eserinde aile içi ilişkilere yer verilir. 
Peyami Safa'nın Gençliğimiz adlı eserinde konu evlenme nedenidir. Yazarın Câzibeli Kız ve Aşağı Katın Kiracıları adlı eserlerinde aldatma konusu işlenir. Yazarın Ava Giden Avlanır adlı eserindeyse evlenme nedeni, aldatma konularının yanında eş seçimi ve eşlerde aranan özellikler konusu yer alır. Sanatçının Siyah Beyaz Hikâyeler adını verdiği çok sayıda hikâyeyi bünyesinde barındıran eserinde boşanma, aldatma, aile içi ilişkiler, aile ve miras; savaş, yangın, doğal âfet ve kazalar; fakir aileler, aile ve ölüm, eş seçimi ve eşlerde aranan özellikler ve evlenme nedeni konuları ele alınır. Yazarın bir

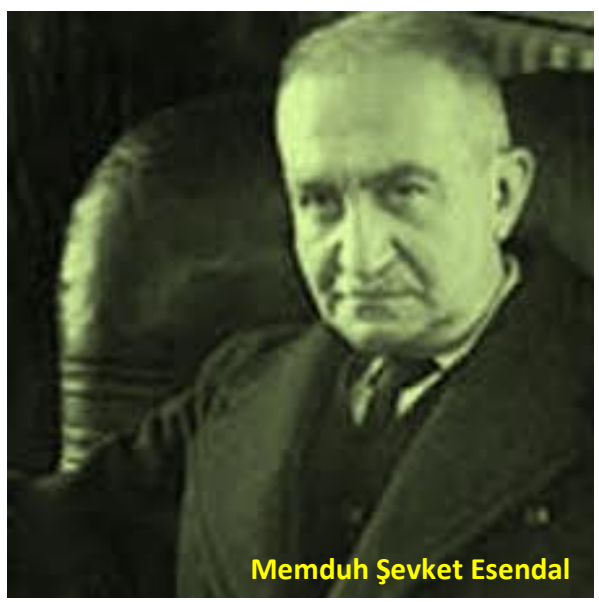
diğer hacimli eseri Asrın Hikâyeleri'ndeyse çok yaşlı bir erkekle çok genç bir kadının evlenmesi, fakir aileler; aile-savaş, yangın, doğal âfet ve kazalar; aldatma, aileye yardımcı elemanlar; hikâye kahramanlarının ve yazarlarının aile ve aileyle ilgili meselelere bakışı; eş seçimi ve eşlerde aranan özellikler, aile içi ilişkiler, evlenme nedeni, ilk evliliğin herhangi bir sebeple bitmesi sonrası evlenme, aile ve ölüm, aile ve miras konuları işlenir.

Selami İzzet Sedes'in Geceye Âşık adlı eserinde aile ve eğitim, hikâye kahramanlarının ve yazarlarının aile ve aileyle ilgili meselelere bakışı, çok yaşlı bir erkekle çok genç bir kadının evlenmesi, aldatma, boşanma, aile ve miras aile içi ilişkiler konuları yer alır. Raif Necdet Kestelli'nin Hisler ve Fikirler adlı eserinde aile içi ilişkiler konusu yanında aile ve gündelik hayat konusu ele alınır.

Memduh Şevket Esendal'ın İhtiyar Çilingir adlı eserinde eş seçimi ve eşlerde aranan özellikler konusu işlenirken Veysel Çavuş,'taysa aile-savaş, yangın, doğal âfet ve kazalar konusu ele alınır. Otlakçı'da aileyle ilgili olarak işlenen konular ise aldatma, memur aileleri, mutlu aileler ve mutluluk sebepleri, aileye gelin veya damat gelişidir. Gödeli Mehmet'te eşlerden birinin hapse girmesi veya sürgüne gönderilmesi, aile-savaş yangın doğal afet ve kazalar, aile içi ilişkiler konusu yer alırken Hava Parası'nda eşlerden birinin hapse girmesi veya sürgüne gönderilmesi; aile-savaş, yangın, doğal afet ve kazalar; aile içi ilişkiler konuları ele alınır.

\section{SONUÇ}

Tanzimat Dönemi'nde aile ve aileyle ile ilgili konulara değinen hikâyelerde aile içindeki yardımcı hizmetlilerin aile içi yaşantıya olan etkileri çok belirgindir. Bu hizmetlilerin çoğu Kafkas, Arap veya Avrupa kökenlidir. Câriye, kalfa, odalık, halayık gibi unvanlara sahip bu kişilerle evlenme veya bu kişiler sebebiyle karı-koca arasında meydana gelen kıskançlık, aldatma meseleleri bu dönem hikâyelerinde önemli bir yer tutar. Bu dönemde kaleme alınan hikâyelerin aileyle ilgili dikkat çeken bir diğer yanı da o günün koşullarına göre gerçekçi olmayan yapay aile tablolarının tasvir edilmesidir. Hikâyelerde ders verme amacının olması da gözden kaçmayan bir diğer husustur.

Servetifünun Dönemi'nde aile ile ilgili konuları ele alan hikâyelerde Batılılaşmış aileler mevcuttur. Salonlarda tertip edilen toplantılarda bir araya gelen aileler birbirleriyle yakın ilişki içerisindedirler. Aile bireylerinden kadınların ve kız evlatların diğer dönemlere nazaran bu 
dönemde sosyal hayatın içinde daha fazla bulunduğu görülür. Bu dönem hikâyelerinde aile ile ilgili olan "aldatma", "boşanma" ve "aile içi ilişkiler" konularına diğer dönemlere göre daha fazla yer verildiği görülür. Bu dönem hikâyelerindeki karakterlerden evlilikte aradığı mutluluğu bulamayan hayâlperver, mutsuz ve kıskanç kadınlar; hasta çocuklar ve onlara üzülen anne-babalar diğer dönemlere nazaran bu dönemde daha fazladır.

Fecriati; muhteva, üslup, dünya görüşü, sanat anlayışı başta olmak üzere birçok bakımdan Servetifünun'un devamı niteliğindedir. Bu benzerliğin izleri bu dönemde kaleme alınan aileyle ilgili hikâyelerde de görmek mümkündür. Her iki dönemde de ailenin aynı üslup ve bakış açısıyla hikâyelerde işlendiği görülür.

Millî Edebiyat Dönemi'nde aileyi konu olarak ele alan hikâyelerde o dönemde yaşanmış olan Balkan Savaşları, 1. Dünya ve Kurtuluş Savaşı'nın olumsuz etkilerinin ailelere nasıl yansıdığı anlatılır. Bu dönem hikâyelerinde yer alan parçalanmış aileler ve bunun çocuklar başta olmak üzere diğer aile üyelerine etkileri gerçekçi bir bakış açısıyla okuyucuya yansıtılır.

Cumhuriyet Öncesi Dönem'de Türk ailesinde meydana gelen bazı değişiklikler bu dönemde kaleme alınan hikâyelere yansır. Bu değişiklikler aile konusunun işlenmesi hususunda edebî dönemler arasında farklılıkların oluşmasına sebep olur. Edebî dönemler arasındaki bu farklılıklar Tanzimat Edebiyatı Dönemi'yle sonrasındaki dönemler arasında kendini daha fazla hissettirir. Bahsedilen bu farklılıkları şu şekilde özetlemek mümkündür: Tanzimat Edebiyatı Dönemi'nde kaleme alınan hikâyelerdeki Türk ailesi geniş aile yapısındayken bu dönem sonrasındaki hikâyelerde Türk ailesi giderek çekirdek aileye doğru evrilir. Aile büyüklerinin ve akrabaların aile üzerindeki etkisi azalır. Kocanın yanında eşi de ailenin geçim sorumluluğunu üstlenir. Ailenin bayan bireyleri sosyal hayat içerisinde daha fazla yer almaya başlar. Çocukların eğitiminde dadı ve mürebbiyelerin yerini resmî ve özel eğitim kurumları alır. Evdeki hizmetlilerle evdeki erkeklerin evlenmesi veya aşk yaşaması gibi olaylar azalır.

Millî Edebiyat Dönemi'ne ait hikâyelerle öncesindeki edebî dönemlere ait hikâyeler arasında aile konusunun işlenişi bağlamında birtakım farklılıklar mevcuttur. Bu farklılıkların başında köy ve kasabalarda yaşayan Anadolu ailesine diğer dönemlere nazaran bu dönemde daha fazla yer verilmesi gelir. Aldatma ve boşanma gibi aileyi sarsan olaylara önceki dönemlere göre daha fazla yer verilmesi; görücü usulü evliliklerin azalması; aile üyelerinin boş zamanlarını birlikte değerlendirme süresinin artması; ailelerin ikâmet ettiği ev tiplerinin değişmesi; ailelerin gündelik hayatı içerisinde yer alan giyim-kuşam alışkanlıkları, mobilya dizaynı, boş zamanları değerlendirme şekilleri vb. Avrupaî tarza daha fazla benzemeye başlaması göze çarpan diğer farklılıklardır.

Cumhuriyet Öncesi Dönem'de kaleme alınan hikâyeler aileyi ilgilendiren konular bağlamında genel bir değerlendirmeye tâbî tutulduğunda özellikle "boşanma, aldatma, ölüm ve savaş gibi aileyi dağıtan veya derinden etkileyen olaylar”, "ailenin kuruluşu ve gelişmesi”, , "aile içi ilişkiler", "aile ve gündelik hayat" konularının diğer konulara nazaran daha fazla işlendiği görülür.

Sonuç olarak; Cumhuriyet Öncesi Dönem'de hikâye türünde eser vermiş olan 37 sanatçıya ait 123 kitap -56 tanesi eski harfli- içerisinde yer alan 1043 hikâyenin -189 tanesi eski harfli- aile 
kurumuyla ilişkisi bağlamında incelenmesi sonucunda hikâyecilerin aile ile ilgili konuları birçok eserde işlediği görülmüştür. İncelenen hikâyeler aracılığıyla bu zaman dilimindeki Türk ailesinin yapısı, ekonomik ve sosyal hayatı başta olmak üzere birçok yönünü görmek mümkündür.

\section{KAYNAKÇA}

Abdullah Zühdî. (2017). Rehgüzâr-ı Matbuâtta. (S. Günaydın, Dü.) Ankara: Cümle Yayınları.

Adıvar, H. E. (1981). Dă̆a Çıkan Kurt. İstanbul: Remzi Kitabevi.

- - . (1967). Harap Mabetler. İstanbul: Atlas Kitabevi.

Ahmet Mithat Efendi. (2013). Durub-ı Emsal-i Osmaniye: Şinasi Hikemiyatının Ahkâmı -Tasvir- (1. b.).

(İ. Enginün, Dü.) İstanbul: Degâh Yayınları.

- - . (2001). Letaif-i Rivayat (1. b.). (F. Gökçek, S. Çağın, Dü) İstanbul: Çağrı Yayınları.

Ahmet Rasim. (r. 1310). Afífe. İstanbul: Âlem Matbaası.

- -. (r. 1316). Bir Sefilenin Evrâk-ı Metrûkesi. Konstantiniye: Babıali Caddesinde 38 Numaralı Matbaa.

- - . (r. 1316). Endişe-i Hayat. İstanbul: Bab-1 Âli Caddesinde 38 Numaralı Matbaa.

- - . (r. 1339). İki Günahsız Sevdâ. İstanbul: İkdam Matbaası.

- - . (2017). İki Güzel (Hamamcı Ülfet). İstanbul: Maviçatı Yayınları.

— - . (2015). İki Güzel Günahkâr. (H. Aydın, Dü.) İstanbul: Kırmızı Kedi Yayınevi.

- - . (1307). Ilk Sevgi. İstanbul: Mekteb-i Sanayi Matbaası.

- - . (1308). Mehâlik-i Hayat. İstanbul: A. Asaduryan Şirket-i Mürettibiye Matbaası.

- - . (1308). Meyl-i Dil. Konstantiniye: Matbaa-i Ebuzziya.

- - . (1315). Nâkâm. Konstantiniye: Mâlumât Matbaası.

— - . (1311). Numûne-i Hayâl. İstanbul: Âlem Matbaası-Ahmed İhsan ve Şürekâsı.

- - . (1308). Tecârib-i hayat. İstanbul: A. Asaduryan Şirket-i Mürettibiye Matbaası.

Aka Gündüz. (1327). Türk Kalbi. İstanbul: Matbaa-i Hukukiye Matbaası.

— - . (1329). Türk'ün Kitabı. İstanbul: Selanik Matbaası.

- - . (1330/1914). Zifaf Hatırası. İstanbul: Cem'i Kütüphanesi.

- -.-Enes Avni müstearıyla-. (r. 1330). Odalı̆̆ın Defteri. İstanbul: Cem'i Kütüphanesi.

Cemil Süleyman. (2014). Bütün Hikayeler. (A. Akın, Dü.) İstanbul: Papersense Yayınları.

Demir, A. (2006). Başlangıcından Cumhuriyet'e Kadar Ana Çizgileriyle Türki Hikâyesi. Başlangıcından Cumhuriyet'e Kadar Ana Çizgileriyle Türkiye Araştırmaları Literatür Dergisi , IV (7), 99-128.

Emin Nihad Bey. (1978-1981). Müsâmeretname Gece Hikâyeleri (1. b.). (M. İ. Uzun, Dü.) İstanbul: Tercüman Gazetesi.

Ercümend Ekrem. (r. 1341). Teravihten Sahura. İstanbul: Orhaniye Matbaası.

Fahri Celâl. (2017). Kedinin Kerameti. İstanbul: Yapı Kredi Yayınları.

Fatma Makbûle Leman. (r. 1331). Ma'kes-i Hayal. İstanbul: Matbaa-i Ahmet İhsan ve Şürekâs1.

Güntekin, R. N. (Yıl Belirtilmemiş). Eski Ahbâb. Basım Yeri Belirtilmemiş: Ahmed ihsan ve Şürekâsı Matbaacılık Osmanlı Şirketi. 
- - . (r. 1335). Recm-Gençlik ve Güzellik. İstanbul: Ahmed İhsan ve Şürekâsı Matbaacılık Osmanlı Şirketi.

— - . (1993). Sönmüş Yıldızlar (11. Baskı b.). İstanbul: İnkılâp Yayınevi.

Gürpınar, H. R. (1966). Kadınlar Vaizi. İstanbul: Atlas Kitabevi.

Halide Edip ; Yakup Kadri; Falih Rıfk1 ; Mehmed Âsım. (r. 1338). İmir'den Bursa'ya, Hikâyeler,

Mektublar ve Yunan Ordusunun Mes'uliyetine Dair Bir Tetkik. İstanbul: Akşam-Teşebbüs Matbaasi.

İzzet Melih. (1922). Hüzün ve Tebessüm (2. b.). İstanbul: Sabah Matbaas1.

Kabaklı, A. (1971). Türk Edebiyatı (3. b., c. I). İstanbul: Türk Edebiyatı Yayınları.

Karaosmanoğlu, Y. K. (2006). Bir Serencam (5. b.). İstanbul: İletişim Yayınları.

Karay, R. H. (1995). Memleket Hikâyeleri. (E. Karay, Dü.) İstanbul: İnkılâp Kitabevi.

Mehmet Celâl. (b. 1318). İsmete Taarruz. İstanbul: A. Asaduryan Şirket-i Mürettibiye Matbaası.

- - (2014). Mehmed Celâl'in Hikâye ve Romanları. (N. Şen, Dü.) Ankara: Kurgan Edebiyat Yayınları.

- - . (r. 1318). Piyano. İstanbul: Şirket-i Mürettibiye Matbaası.

- - . (1317). Solgun Yadigârlar. İstanbul: A. Asaduryan Şirket-i Mürettibiye Matbaası.

_ - . (r. 1324). Zindan Kapısında. İstanbul: Matbaa-i Ahmet Kâmil.

Mehmet Rauf. (r. 1325). Âşıkâne. İstanbul: Hilal Matbaası.

- - . (r. 1330). Hanımlar Arasında. Dersaadet: Kanaat Matbaası.

— - . (r. 1325). İhtizar. İstanbul: Hilal Matbaası.

— - . (r. 1338). İlk Temas İlk Zevk. İstanbul: Kütüphane-i Sûdî.

- - . (r. 1330). Kadın İsterse. İstanbul: Melâl Matbaası.

— - . (2007). Mehmed Rauf Seçme Hikâyeler. (R. Tarım, Dü.) İstanbul: 2007.

- - . (1920). Pervaneler Gibi. İstanbul: Orhaniye Matbaası.

- - . (2017). Son Emel. İstanbul: Mühür Kitaplığı Yayınları.

- - . (2011). Üç Hikâye. (R. Tarım, Dü.) İstanbul: Özgür Yayınları.

Mehmet Vecihî. (1314/1898). Halime. Dersaadet: İkdam Matbaası.

- - . (r. 1315). Hasbihâl. İstanbul: Şirket-i Mürettibiye Matbaası.

- - . (r. 1314). Hikâye-i Muntehabe Mecmûası. Dersaâdet: İkdam Matbaası.

- - . (r. 1314). Nerîme. İstanbul: Malumat Matbaası.

- - . (r. 1315). Netîce yahud Bir Yetimin Sergüzeşti. İstanbul: Asır Matbaası.

- - . (r. 1315). Vuslat. İstanbul: Asır Matbaası.

Mehmet Rıfat. (r. 1326). Gönüllü/Henüz On Altı Yaşında. İstanbul: Artin Asaduryan Matbaası.

Mustaf Reşit. (r. 1312). Tesâvir-i Hayat. İstanbul: İstepan Matbaası.

- - . (r. 1304). Hanım Mektupları (2. Baskı b.). İstanbul: Matbaa-i Ebuzziyâ.

Mutluay, R. (1976). 50 Yılın Türk Edebiyatı (3. b.). İstanbul: İş Bankası Kültür Yayınları.

Müftüoğlu, A. H. (1971). Çağlayanlar. İstanbul: Millî Eğitim Basımevi.

- - . (1969). Haristan ve Gülistan (3. b.). İstanbul: Ötüken Yayınevi. 
- - . (1308/). Leyla yahud Bir Mecnun'un İntikamı. İstanbul: Asır Kütüphanesi.

Münir Süleyman. (r. 1330). Düğ̈̈̈n Gecesi Să̆ır Güveyin Muaşakası. İstanbul: Mesâi Matbaası.

Nâbizâde Nâzım. (2015). Karabibik ve Diğer Hikâyeler (1. b.). (S. Çağan, N. Kurudere, Dü) İstanbul: Dergâh Yayınları.

Osman Cemâl. (r. 1339-1341). Altın Babası. İstanbul: Cihan Biraderler Matbaası.

- - . (r. 1339-1341). Çuvalcı Şeyhinin Halefi. İstanbul: Sabah Matbaası.

Ömer Seyfettin. (2017). Ömer Seyfettin Bütün Eserleri Hikâyeler 1 (5. b.). (H. Argunşah, Dü.) İstanbul: Dergâh Yayınları.

- - . (2017). Ömer Seyfettin Bütün Eserleri Hikâyeler 2 (4. b.). İstanbul: Dergâh Yayınları.

- - . (2017). Ömer Seyfettin Bütün Eserleri Hikâyeler 3 (4. b.). (H. Argunşah, Dü.) İstanbul: DergâhYayınları.

- - . (2014). Ömer Seyfettin Bütün Eserleri Hikâyeler 4 (3. b.). (H. Argunşah, Dü.) İstanbul: Dergâh Yayınları.

Peyami Safa. (r. 1335). Aşă̆̊ Katın Kiracıları. İstanbul: Necm-i İstikbâl Matbaası.

— - . (r. 1338). Ava Giden Avlanır. İstanbul: Necm-i İstikbâl Matbaası.

- - . (r. 1336). Cazibeli Kız. İstanbul: Necm-i İstikbal Matbaası.

- - . (r. 1338). Gençliğimiz. İstanbul: Orhaniye Matbaası.

- - (1980). Hikâyeler. İstanbul: Ötüken Yayınları.

Râif Necdet. (r. 1317-1326). Hisler ve Fikirler. İstanbul: Matbaa-i Hayriye ve Şürekâsı.

Recaizade Mahmut Ekrem. (2014). Muhsin Bey Yahut Şâirliğin Hazin Bir Neticesi. (A. M. Kot, S. Yalçın, Dü, B. Ülger, Çev.) İstanbul: Papersense Yayınları.

— - . (r. 1313). Şemsa. İstanbul: Âlem Matbaası.

Safvetî Ziya. (2017). Bir Safha-i Kalb. (M. Balık, Dü.) Ankara: Gece Kitaplığı Yayınları.

- - . (2016). Hanım Mektupları. (M. K. Özgül, Dü.) Ankara: Cümle Yayınları.

- - . (r. 1330). Kadın Ruhu. İstanbul: Tanin Matbaası.

Samipaşazade Sezai. (2003). Samipaşazade Sezai Bütün Eserleri (1.Baskı b., Cilt 1). (Z. Kerman, Dü.) Ankara: Atatürk Kültür, Dil ve Tarih Yüksek Kurumu Türk Dil Kurumu Yayınları.

Sedes, S. İ. (2015). Geceye Âşık \& Gönül Sarmaşıkları. (M. Aydemir, Dü.) Erzurum: Salkımsöğüt Yayınlar1.

Selahaddin Enis. (r. 1339-1342). Sara. İstanbul: Orhaniye Matbaası.

Şen, C. (2009). Fecriati Encümeni Edebiyat1. Turkish Studies International Periodical For the Languages, Literature and History of Turkish or Turkic , 4/1-II , 1333-1426.

Tepeyran, E. H. (2017). Eski Şeyler. (İ. Özen, T. Özen, Dü) İstanbul: Dün Bugün Yarın Yayınları. Tokgöz, A. İ. (r. 1308). Bahse Ne Dersiniz. Konstantiniye: Âlem Matbaası.

— - . (r. 1307). Küçük Fıkralar. İstanbul: Âlem Matbaası.

- - . (r. 1308). Postaci. Konstantiniye: Âlem Matbaası.

Uşaklıgil, H. Z. (1987). Bir Hikâye-i Sevda. (Ş. Kutlu, Dü.) İstanbul: İnkılâp Kitabevi.

- - . (r. 1306). Bir İzdivacın Tarih-i Muaşakası. İstanbul: Mihran Matbaası.

— - . (r. 1330). Bir Şi'r-i Hayal. İstanbul: Matbaa-i Hayriye ve Şürekâsı. 
- - . (2005). Bir Yazın Tarihi. (K. Andı, Dü.) İstanbul: Özgür Yayınları.

- - . (2016). Bu muydu? (M. Çevikdoğan, Dü.) İstanbul: Can Yayınları.

- - . (r. 1316). Heyhat. Konstantiniyye: Ahmet İhsan ve Şürekası Âlem Matbaası.

- - . (2004). Küçük Fıkralar. (F. Aslan, Dü.) İstanbul: Özgür Yayınları.

- - . (r. 1312). Nâkil. Konstantiniyye: Matbaa-i Ebuzziya.

- - . (2010). Sepette Bulunmuş/Hepsinden Acı. (D. Soğanoğlu, Dü.) İstanbul: Özgür Yayınları.

- - . (1987). Solgun Demet. (Ş. Kutlu, Dü.) İstanbul: İnkılâp Kitabevi.

Yalçın, H. C. (2013). Hayat-ı Hakîkiye Sahneleri. (F. Arslan, Dü.) Konya: Salkımsöğüt Yayınları.

- - . (r. 1326). Hayât-ı Muhayyel (3. Baskı b.). İstanbul: İkdam Matbaası.

- - . (1943). Niçin Aldatırlarmış? İstanbul: Ahmet Halit Kitabevi. 


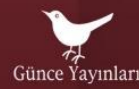

Prof. Dr. Önder Göçgün

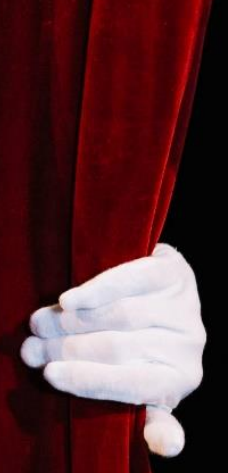

TIYYATRO DENEN HAYAT

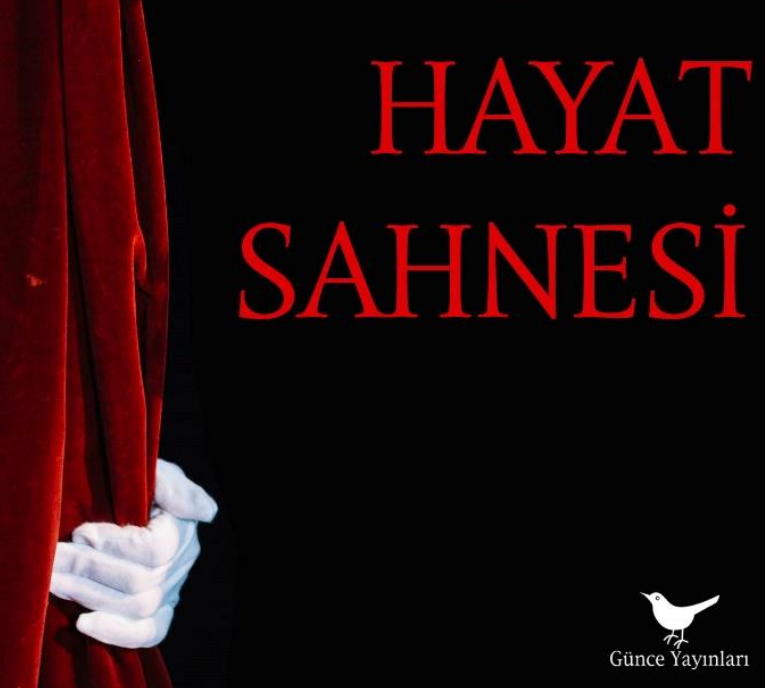

MUIIARREM DAYANC OKTAY YIVLI MACI'I BALIK MAIIMU'I BABACAN SLVIM SLERMEI
YASFMIN MUMCU BLDI் KOÇАKOĞLU NILÜLLLR ILLHAN MAKSUT YIĞITBAS SLL $\triangle M I I L \Lambda N$

\section{EDEBIYATINDA

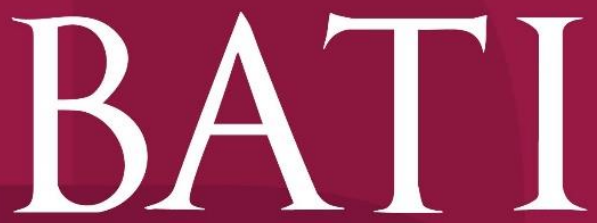 \\ EDEBIYATINDA
AKIMLAR \\ $\underset{\substack{\text { EDEBIYATINDA } \\ \text { AKIMLAR }}}{\mathrm{B} A T \mathrm{~T}}$}

editör

OKTAY YIVLI

HATICE FIRAT

YASEMIN MUMCU

OKTAY YIVLI

OĞUZHAN KARABURGU

BERNA AKYÜZ SIZGEN

NILÜFER ILHAN
ÜMMÜHAN TOPÇU

SEFA YÜCE

HANIFI ASLAN

METIN AKYÜZ

MEHMET SÜMER
YAKUP ÖZTÜRK
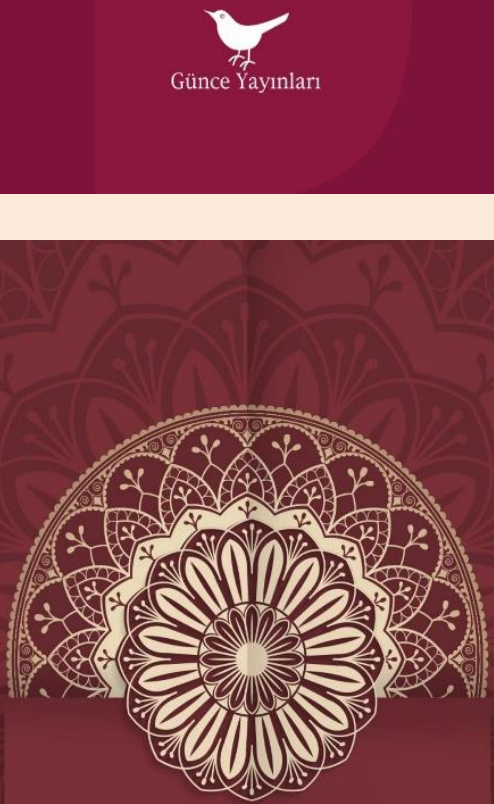

PROF. DR. ÖNDER GÖÇGÜN

$$
\begin{gathered}
\text { Türk } \\
\text { Tasavvuf } \\
\text { Siini }
\end{gathered}
$$

AÇIKLAMALI VE YORUMLU ÖRNEKLERLE 